\title{
Sarmentine, a natural herbicide from Piper species with multiple herbicide mechanisms of action
}

\author{
Franck E. Dayan ${ }^{1 *}$, Daniel K. Owens ${ }^{1}$, Susan B. Watson ${ }^{1}$, Ratnakar N. Asolkar ${ }^{2}$ and \\ Louis G. Boddy ${ }^{2}$ \\ ${ }^{1}$ Natural Products Utilization Research Unit, US Department of Agriculture-Agricultural Research Service, Thad Cochran \\ Center, University of Mississippi, MS, USA, ${ }^{2}$ Marrone Bio Innovations, Davis, CA, USA
}

\section{OPEN ACCESS}

Edited by:

Daniel Anthony Dias,

The University of Melbourne, Australia

Reviewed by:

Massuo Jorge Kato, University of São Paulo, Brazil

Giorgia Sarais,

University of Cagliari, Italy

*Correspondence:

Franck E. Dayan,

Natural Products Utilization Research

Unit, US Department of

Agriculture-Agricultural Research

Service, Thad Cochran Center,

University of Mississippi, 1558 University Avenue, MS 38677, USA

franck.dayan@ars.usda.gov;

fdayan@olemiss.edu

ORCID ID 0000-0001-6964-2499

Specialty section: This article was submitted to Plant Metabolism and Chemodiversity, a section of the journal Frontiers in

Plant Science

Received: 26 January 2015 Accepted: 20 March 2015 Published: 08 April 2015

Citation:

Dayan FE, Owens DK, Watson SB, Asolkar RN and Boddy LG (2015) Sarmentine, a natural herbicide from

Piper species with multiple herbicide mechanisms of action. Front. Plant Sci. 6:222. doi: 10.3389/fpls.2015.00222
Sarmentine, 1-(1-pyrrolidinyl)-(2E,4E)-2,4-decadien-1-one, is a natural amide isolated from the fruits of Piper species. The compound has a number of interesting biological properties, including its broad-spectrum activity on weeds as a contact herbicide. Initial studies highlighted a similarity in response between plants treated with sarmentine and herbicidal soaps such as pelargonic acid (nonanoic acid). However, little was known about the mechanism of action leading to the rapid desiccation of foliage treated by sarmentine. In cucumber cotyledon disc-assays, sarmentine induced rapid light-independent loss of membrane integrity at $100 \mu \mathrm{M}$ or higher concentration, whereas $3 \mathrm{mM}$ pelargonic acid was required for a similar effect. Sarmentine was between 10 and 30 times more active than pelargonic acid on wild mustard, velvetleaf, redroot pigweed and crabgrass. Additionally, the potency of $30 \mu \mathrm{M}$ sarmentine was greatly stimulated by light, suggesting that this natural product may also interfere with photosynthetic processes. This was confirmed by observing a complete inhibition of photosynthetic electron transport at that concentration. Sarmentine also acted as an inhibitor of photosystem II (PSII) on isolated thylakoid membranes by competing for the binding site of plastoquinone. This can be attributed in part to structural similarities between herbicides like sarmentine and diuron. While this mechanism of action accounts for the light stimulation of the activity of sarmentine, it does not account for its ability to destabilize membranes in darkness. In this respect, sarmentine has some structural similarity to crotonoyl-CoA, the substrate of enoyl-ACP reductase, a key enzyme in the early steps of fatty acid synthesis. Inhibitors of this enzyme, such as triclosan, cause rapid loss of membrane integrity in the dark. Sarmentine inhibited the activity of enoyl-ACP reductase, with an $I_{50}$ app of $18.3 \mu \mathrm{M}$. Therefore, the herbicidal activity of sarmentine appears to be a complex process associated with multiple mechanisms of action.

Keywords: mode of action, photosystem II, electrolyte leakage, membrane integrity, enoyl ACP reductase, herbicide resistance, herbicide discovery

\section{Introduction}

Herbicides benefit food production by reducing weed pressure and improving the quality of crop products (Gianessi and Reigner, 2007). However, concerns over their potential adverse effect on the environment and human health are leading consumers to desire agricultural crops produced with 
greener technologies (Solomon and Schettler, 2000; Stillerman et al., 2008). Additionally, reliance on herbicides has led to the emergence of resistance among many weed species (Délye et al., 2013; Service, 2013; Heap, 2015). Therefore, there is a need to develop alternative ecofriendly, economical and efficacious means for weed management. To that end, there is a renewed interest in discovering and developing new biopesticides (Cantrell et al., 2012; Dayan et al., 2012).

Bioherbicides, such as pelargonic acid, are non-selective and less potent than their synthetic counterparts, requiring multiple applications at relatively high concentrations (Young, 2004; Barker and Prostak, 2009). However, some natural products have served as templates for the development of several successful herbicides (glufosinate and the triketone herbicides) (Cantrell et al., 2012) that introduced new mechanisms of action, which is greatly needed to combat the evolution of resistance to herbicides in production agriculture (Duke et al., 2013). There is, therefore, a great interest in exploring natural products to develop new bioherbicides (Hüter, 2011; Dayan et al., 2012; Gerwick and Sparks, 2014). Natural products are particularly attractive as templates because they occupy a wider chemical space with greater structural diversity than traditional synthetic compounds (Koch et al., 2005; Lipkus et al., 2008; Li and Vederas, 2009; Valli et al., 2013).

Piper species produce a large number of bioactive molecules with great economic value (Parmar et al., 1997). Yet, this may only represent a small portion of the true breadth of the chemical richness of Piper metabolites since only a limited number of Piper species have been characterized (Dyer et al., 2004). Piper amides (e.g., piperidine amides) are a particularly prevalent group of neutral to weakly acidic bioactive products (Likhitwitayawuid et al., 1987; Banerji and Das, 1989), with medicinal (Wang et al., 2014), insecticidal (Yang et al., 2002; Scott et al., 2008), antifungal (Alécio et al., 1998; Da Silva et al., 2014), and antiherbivory activity (Dyer et al., 2001).

Sarmentine, 1-(1-pyrrolidinyl)-(2E,4E)-2,4-decadien-1-one, is a Piper amide with several biological properties, including antiplasmodial, antimycobacterial, and antituberculosis activity (Rukachaisirikul et al., 2004; Tuntiwachwuttikul et al., 2006), as well as antiplatelet aggregation ( $\mathrm{Li}$ et al., 2007). Interest in sarmentine as a biopesticide renewed when its herbicidal activity was discovered through a bioactivity-guided isolation of the active components of the fruits of Piper sarmentosum and Piper nigrum (Huang et al., 2010). Sarmentine acts as a contact herbicide with broad-spectrum activity in a similar way as herbicidal soaps such as nonanoic acid (pelargonic acid) or decanoic acid.

Most natural contact herbicides (pelargonic acid, essential oils) are used as desiccants and act by stripping the cuticular wax layer covering the surface of leaves (Fukuda et al., 2004; Coleman and Penner, 2006, 2008). The rapid desiccation of foliage treated by sarmentine suggests that this Piper amide has a similar mechanism of action. However, evidence that sarmentine acted in this way was lacking and this study investigates the mechanism of action of this biopesticide using methods developed in our laboratory (Dayan et al., 2000a, 2015).

\section{Materials and Method}

\section{Isolation and Weed Spectrum of Sarmentine}

Sarmentine was purified from long pepper fruit according to a protocol developed previously (Huang et al., 2010). All seedlings of weeds were planted in $5.7 \times 5.7 \times 6.2 \mathrm{~cm}$ or $8 \times 8 \times$ $7.2 \mathrm{~cm}$ plastic pots. All pots were stored in a growth room with $28^{\circ} \mathrm{C}$ temperature and $60 \%$ humidity. Seedlings including the broadleaf weeds wild mustard [Brassica kaber (DC.) L.C. Wheeler], pigweed (Amaranthus retroflexus L.), lambsquarters (Chenopodium album L.), velvetleaf (Abutilon theophrasti Medik.), common purslane (Portulaca oleracea L.), dandelion (Taraxacum officinale G.H. Weber ex Wiggers), bindweed (Convolvulus arvensis L.), spurge (Euphorbia sp.), common chickweed [Stellaria media (L.) Vill.], coffeeweed [Sesbania exaltata (Raf.) Rydb. ex A.W. Hill], white clover (Trifolium repens L.) and buckhorn plantain (Plantago lanceolata L.), and monocotyledonous weeds smallflower umbrella sedge (Cyperus difformis L.), goosegrass [Eleusine indica (L.) Gaertn.], large crabgrass [Digitaria sanguinalis (L.) Scop], annual bluegrass (Poa annua L.), late watergrass [Echinochloa phyllopogon (Stapf) Koss], quackgrass [Elytrigia repens (L.) Gould], smooth crabgrass [Digitaria ischaemum (Schreb.) Schreb. ex Muhl.] and yellow nutsedge (Cyperus esculentus L.), were planted in potting soil mixture. When treated, all seedlings were at the 2-3 true leaf stage. Visual injury was evaluated using the following rating scale: $+=0-50 \%$, $++=51-80 \%,+++=81-90 \%$, and $++++=91-100 \%$ injury.

Plants in the growth room were treated with formulated sarmentine. The proprietary formulation consists of 50\% sarmentine, with the remainder comprised of inert ingredients; it does not include any other herbicidal compounds. Pots were sprayed with the equivalent of $10 \mathrm{mg}$ sarmentine $\mathrm{ml}^{-1}$ in water; no additional surfactant was added. Solutions were applied with a Generation III track sprayer (DeVries Manufacturing, Hollandale, MN, USA) equipped with a model TeeJet EZ 8002 nozzle (Spraying Systems Co., Wheaton, IL, USA) with conical pattern and $80^{\circ}$ spray angle. The height from nozzle to soil level was $71 \mathrm{~cm}$ for the experiments. The spray head was set to move over the plants at $1.7 \mathrm{~km} \mathrm{~h}^{-1}$, and the sprayer was calibrated to deliver the equivalent of $374 \mathrm{l} \mathrm{ha}^{-1}$.

\section{Leaf Surface Microscopy}

Leaves were collected from 2 to 3 week-old plants for scanning electron microscopy observation. To preserve the appearance of the cuticles, samples were processed without fixation and dehydration by flash-freezing in supercooled nitrogen slush at $-210^{\circ} \mathrm{C}$ for $5 \mathrm{~s}$ according to Hayat (2000). The frozen samples were placed in $1 \mathrm{~kg}$ brass receptacles supercooled in liquid nitrogen $\left(-196^{\circ} \mathrm{C}\right)$ to keep the leaves frozen during the initial stages of lyophilization at $-50^{\circ} \mathrm{C}$. The lyophilized leaf samples were then placed on aluminum stubs with their adaxial surfaces exposed and coated with a layer of gold-palladium (15 mA under 75 mTorr pressure) using a Hummer 6.2 sputter coater (Anatech USA, Union City, CA 94587). The adaxial surfaces of several samples of each species were observed with a scanning electron microscope (JEOL JSM-5600, Peabody, MA 01960). The images 
were digitally colorized using Adobe Photoshop CS4 (Adobe, San Jose, CA 95110).

\section{Electrolyte Leakage}

The effect of sarmentine and pelargonic acid on plasma membrane integrity was tested by measuring electrolyte leakage as described before (Dayan and Watson, 2011). Briefly, cucumber seedlings [Cucumis sativus (L.) var. straight eight] were maintained in a growth chamber with a 16/8 light/dark cycle for 10 days. Twenty-five $4-\mathrm{mm}$ cotyledon discs were incubated in the presence of different concentrations of the sarmentine or pelargonic acid. Sarmentine and pelargonic acid stocks (100X) were made in acetone. Control tissues were exposed to the same amount of acetone $(1 \%[\mathrm{v} / \mathrm{v}])$ as treated tissues but without test compounds. Plates were incubated in darkness for $24 \mathrm{~h}$ prior to exposure to high light intensity $\left(1000 \mu \mathrm{mol} \mathrm{m}^{-2} \mathrm{~s}^{-1}\right)$ photosynthetically active radiation (PAR).

Measurements were made using an electrical conductivity meter (Model 1056, Amber Science, Eugene, OR 97402) equipped with a model 858 Conductivity Macro Flow cell. Measurements were taken at the start of the experiment, at the end of the dark incubation period, and after exposure to high light intensity. The experiment was repeated over time and consisted of three replicates.

Subsequent experiments with velvetleaf (Abutilon theophrast $i$ Medik.), redroot pigweed (Amaranthus retroflexus L.), mustard [Brassica juncea (L.) Czern] and large crabgrass [Digitaria sanguinalis (L.) Scop.] consisted of a measurement of the conductivity in the bathing medium at the beginning of the experiment and after $24 \mathrm{~h}$ incubation in darkness.

\section{Induced Chlorophyll Fluorescence}

The effect of sarmentine on photosynthesis was initially tested on cucumber cotyledons from the leakage experiments using a pulse-modulated fluorometer (Opti-Science, Model OS5-FL, Tyngsboro, MA 01879). The instrument was set on Kinetic Mode and adjusted so that the initial Ft (instantaneous fluorescence signal) value in the control samples was approximately 210 . The other parameters were as described in a previous publication (Dayan and Zaccaro, 2012).

\section{Inhibition of Oxygen Evolution in Isolated Thylakoid Membranes}

Thylakoid membranes were isolated from spinach, or wild-type and triazine-resistant redroot pigweed (Amaranthus retroflexus L.) as described elsewhere (Rimando et al., 1998; Dayan et al., 2009a), except that the thylakoid membranes were further purified on a $30-52 \%$ sucrose step gradient centrifugation in a SW40 Ti swinging bucket rotor and an XL-90 Beckman (Beckman Coulter, Inc., Brea, CA 92821-6232 USA) centrifuge at 28,000 $\mathrm{g}$ for $1 \mathrm{~h}$ at $4^{\circ} \mathrm{C}$ (Dayan et al., 2009b). Thylakoid membranes were diluted to $4 \mathrm{mg}$ of chlorophyll $\mathrm{ml}^{-1}$ for the oxygen evolution experiments and to $1 \mathrm{mg}$ of chlorophyll ml $\mathrm{ml}^{-1}$ for the binding kinetic experiments.

\section{Oxygen Evolution Assay}

$\mathrm{O}_{2}$ evolution assays were conducted under saturating light conditions $\left(10 \mathrm{mmol} \mathrm{m}^{-2} \mathrm{~s}^{-1}\right.$ PAR) with the use of a fiber-optic light source delivering 1300 lumen (Schott-Foster, LLC, Southbridge, MA 01550 USA) and measured using a Hansatech OXYGRAPH PLUS Oxygen Electrode System (PP System, Amesbury, MA 01913 USA) as described elsewhere (Dayan et al., 2009b). Sarmentine and atrazine were diluted in acetone, and control treatments received the same concentration of solvent (less than $1 \% \mathrm{v} / \mathrm{v})$. Membrane preparations were incubated with test compounds $(0-3 \mathrm{mM})$ on ice for $20 \mathrm{~min}$ prior to the assay. The assay was initiated by addition of thylakoid membranes to the reaction assay buffer, and the rate of oxygen evolution was measured for $120 \mathrm{~s}$ over the linear portion of the curve. Data are expressed as $\mu \mathrm{mol} \mathrm{O}_{2} \mathrm{l}^{-1} \mathrm{~min}^{-1}$.

\section{Binding Kinetics of Sarmentine on $Q_{B}$ Binding Site of Photosystem II}

$\left[{ }^{14} \mathrm{C}\right]$-atrazine was bound to spinach thylakoid membranes in the presence or absence of sarmentine according to Tischer and Strotmann (1977) as modified by Dayan et al. (2000b). Thylakoid membranes $\left(100 \mu \mathrm{g}\right.$ of chlorophyll $\left.\mathrm{ml}^{-1}\right)$ were suspended in a $1-\mathrm{ml}$ reaction solution consisting of $330 \mathrm{mM}$ sorbitol, $100 \mathrm{mM}$ HEPES ( $\mathrm{pH} 7.7$ ), $1 \mathrm{mM}$ EDTA, and $1 \mathrm{mM} \mathrm{MgCl}_{2}$. A half-log dilution series $\left(33-0.03 \mu \mathrm{M}\right.$ ) of $\left[{ }^{14} \mathrm{C}\right]$-atrazine (uniformly labeled with specific activity of $160 \mathrm{mCi} \mathrm{mmol}^{-1}$, American Radiolabeled Chemicals Inc, St. Louis, MO) and $10 \mu \mathrm{M}$ unlabeled sarmentine was added. The suspensions were thoroughly mixed and incubated for $15 \mathrm{~min}$ on ice. The samples were centrifuged $(6 \mathrm{~min}$, $\left.12,000 \mathrm{~g}, 4^{\circ} \mathrm{C}\right)$. The supernatant was transferred to vials and mixed with $18 \mathrm{ml}$ of premixed scintillation cocktail (Ultima Gold, Packard Instrument) for radioactivity measurements. The inner walls of tubes were dried with cotton swabs without disturbing the pellets to remove excess $\left[{ }^{14} \mathrm{C}\right]$-atrazine. A $100-\mu l$ aliquot of tissue solubilizer (Soluene-350, Packard Instrument Co. Meriden, CT 06450) was added to the pellets and heated in a water bath at $50^{\circ} \mathrm{C}$ for $15 \mathrm{~min}$. The slurry was neutralized with $50 \mu \mathrm{l}$ of $1 \mathrm{M}$ Tris- $\mathrm{HCl}$ buffer ( $\mathrm{pH} 7.0)$ and transferred to scintillation vials. Ethanol $(20 \mu \mathrm{l})$ used to wash the inner walls of each tube was combined with the slurry before radioactivity measurements. The amount of bound $\left[{ }^{14} \mathrm{C}\right]$-atrazine was calculated from the radioactivity in the pellets. Binding for atrazine and sarmentine was determined from double-reciprocal plots of bound atrazine vs. free atrazine (Tischer and Strotmann, 1977). All regressions and intercepts were calculated in SigmaPlot (version 12, Systat Software Inc., San Jose, CA, USA).

\section{Inhibition of Enoyl-ACP Reductase (ENR)}

Arabidopsis thaliana ENR was cloned in Escherichia coli and expressed as described elsewhere (Dayan et al., 2008). Briefly, cells were collected by centrifugation, resuspended in cold lysing buffer [ $50 \mathrm{mM}$, Tris- $\mathrm{HCl}$ ( $\mathrm{pH} 7.5$ ), $1 \mathrm{M} \mathrm{NaCl}, 5 \mathrm{mM}$, imidazole, $10 \%\left[\mathrm{v} / \mathrm{v}\right.$ ] glycerol, $1 \mu \mathrm{g} \mathrm{ml}^{-1}$ leupeptin] and lysed with a French Press (Glen Mills Inc., Clifton, NJ). Debris was removed by centrifugation and the ENR in the supernatant was purified on a nickel activated HisTrap HP column (GE Healthcare BioSciences). The ENR containing fraction was desalted on a PD-10 column equilibrated with cold desalting buffer $(10 \mathrm{mM}$ sodium phosphate, $\mathrm{pH} 7.2,10 \mathrm{mM}$ dithiothreitol, 10\% [v/v] glycerol). 
Protein concentration was determined using Bio-Rad protein reagent.

ENR activity was measured in $10 \mathrm{mM}$ sodium phosphate, $\mathrm{pH}$ 7.2 assay buffer as described before (Dayan et al., 2008). The $I_{50}$ values (concentration of inhibitor required for $50 \%$ inhibition of activity) of sarmentine, pelargonic acid, and triclosan on A. thaliana ENR were determined by testing the inhibitors at concentrations ranging from 0.1 to $100 \mu \mathrm{M}$. All inhibitors were dissolved in acetone and control samples received equivalent amounts of acetone $(1 \%[\mathrm{v} / \mathrm{v}]$ final concentration). The reactions were started by addition of NADH. The oxidation of NADH was monitored for $60 \mathrm{~s}$ by measuring change in A340 in a Shimadzu model UV3101PC spectrophotometer with the cell thermostabilized at $25^{\circ} \mathrm{C}$. Spectrophotometric measurements were converted to concentrations of NADH oxidized using $\varepsilon=6.3 \mathrm{mM}^{-1} \mathrm{~cm}^{-1}$ (Ward et al., 1999).

\section{L-Amino Acid Oxidase Assay}

All reagents, including the amino acid oxidase and peroxidase enzymes, were obtained from Sigma. The activity of L-amino acid oxidase was measured at $37^{\circ} \mathrm{C}$ using a Shimadzu spectrophotometer by measuring the increase in absorption at $436 \mathrm{~nm}$ via a peroxidase-coupled secondary reaction. The reaction buffer consisted of $0.2 \mathrm{M}$ triethanolamine, $\mathrm{pH} 7.8$ containing $0.1 \%$ L-leucine and $0.0065 \% o$-dianisidine (Fast Blue B). Baseline conditions were established by adding $10 \mu \mathrm{l}$ of a $10 \mathrm{mg} \mathrm{ml}^{-1}$ solution of peroxidase to $2.9 \mathrm{ml}$ of reaction buffer in a cuvette. The cuvette was placed in the spectrophotometer and the temperature allowed to equilibrate for $5 \mathrm{~min}$. The reaction was initiated by adding $100 \mu \mathrm{l}$ of amino acid oxidase ( 0.027 units) to the cuvette and mixing. The amino acid oxidase was preincubated with $3 \mathrm{mM}$ sarmentine or acetone for $15 \mathrm{~min}$ before measuring activity. The final concentration in the assay was $100 \mu \mathrm{M}$ sarmentine.

\section{Computer Modeling}

Sarmentine and diuron were built using the fragment library of Spartan version 6.1 (Wavefunction, Inc., Irvine, CA) and minimized using the equilibrium geometry at ground state, by applying the semiempirical AM1 (Austin Model) parameterization starting with the MMFF (molecular mechanics force fields) geometry. Sarmentine and diuron were aligned along their amide moiety using the align function of Spartan. The $\pi$-charge distribution over the amide bond was visualized by applying the ionization calculation to the potential surface map.

\section{Statistical Analysis}

Dose-response curves were analyzed by a four-parameters loglogistic model (Seefeldt et al., 1995) using R software (version 2.15.2, R Foundation for Statistical Computing, Vienna, Austria) with the drc module (Ritz and Streibig, 2005). Means and standard deviations were obtained using the raw data and the half-maximal inhibitory response $\left(I_{50}\right)$ was defined as the concentration at which this accumulation was inhibited by $50 \%$ compared with controls. $I_{50}$ values were obtained from the parameters in the regression curves. Graphs were generated with Sigma Plot. Means were separated with the Duncan multiple range test at $P=0.05$ using the Agricolae module (De Mendiburu, 2014).

\section{Results}

\section{Weed Spectrum of Sarmentine}

Sarmentine was sprayed on selected broadleaf and grass weeds to determine its spectrum of activity. Wild mustard and pigweed were the most sensitive to sarmentine, with greater than 91\% injury 7 days after treatment (Table 1). A number of broadleaf and grass weeds sustained between 81 and $90 \%$ injury (Tables 1, 2).

\section{Alteration of the Leaf Surface Ultrastructure by Sarmentine}

The adaxial leaf surface of velvetleaf consists of relatively smooth cuticle over the epidermal cells interspersed with stomata, glandular trichomes and star-shaped hairs over the surface (Figures 1A,B). The deposition of sarmentine over the leaf surface is visible within $1 \mathrm{~h}$ of application as a small residue scattered

TABLE 1 | Herbicidal activity of sarmentine on selected broadleaf weeds 7 days after treatment.

\begin{tabular}{|c|c|c|c|}
\hline $\begin{array}{l}\text { Common } \\
\text { name }\end{array}$ & $\begin{array}{l}\text { Scientific } \\
\text { name }\end{array}$ & $\begin{array}{l}\text { Bayer } \\
\text { code }\end{array}$ & $\begin{array}{c}\text { Treatment } \\
\left(20 \mathrm{mg} \mathrm{ml}^{-1}\right)^{\mathrm{a}}\end{array}$ \\
\hline Wild mustard & Brassica kaber & SINAR & ++++ \\
\hline Pigweed & Amaranthus retroflexus & AMARE & ++++ \\
\hline Lambsquarters & Chenopodium album & CHEAL & +++ \\
\hline Velvetleaf & Abutilon theophrasti & ABUTH & +++ \\
\hline Common purslane & Portulaca oleracea & POROL & +++ \\
\hline Dandelion & Taraxacum officinale & TAROF & +++ \\
\hline Bindweed & Convolvulus arvensis & CONAR & +++ \\
\hline Spurge & Euphorbia spathulata & EPHSQ & ++ \\
\hline Common chickweed & Stellaria media & STEME & ++ \\
\hline Coffeeweed & Sesbania exaltata & SEBEX & ++ \\
\hline White clover & Trifolium repens & TRFRE & + \\
\hline Buckhorn plantain & Plantago lanceolata & PLALA & + \\
\hline
\end{tabular}

a Ratings: $+=0-50 \%,++=51-80 \%,+++=81-90 \%$, and $++++=91-100 \%$ weed injury.

TABLE 2 | Herbicidal activity of sarmentine on selected monocotyledonous weeds 7 days after treatment.

\begin{tabular}{lllc}
\hline $\begin{array}{l}\text { Common } \\
\text { name }\end{array}$ & $\begin{array}{l}\text { Scientific } \\
\text { name }\end{array}$ & $\begin{array}{l}\text { Bayer } \\
\text { code }\end{array}$ & $\begin{array}{c}\text { Treatment } \\
\left(\mathbf{2 0} \mathbf{~ m g ~} \mathbf{~ m}^{-\mathbf{1}} \mathbf{~}^{\mathbf{a}}\right.\end{array}$ \\
\hline Smallflower sedge & Cyperus difformis & CYPDI & +++ \\
Goosegrass & Eleusine indica & ELEIN & ++ \\
Large crabgrass & Digitaria sanguinalis & DIGSA & ++ \\
Annual bluegrass & Poa annua & POAAN & ++ \\
Late watergrass & Echinochloa phyllopogon & ECHPH & + \\
Quackgrass & Elytrigia repens & AGRRE & + \\
Smooth crabgrass & Digitaria ischaemum & DIGIS & + \\
Yellow nutsedge & Cyperus esculentus & CYPES & + \\
\hline
\end{tabular}

${ }^{a}$ Ratings: $+=0-50 \%,++=51-80 \%,+++=81-90 \%$, and $++++=91-100 \%$ weed injury. 


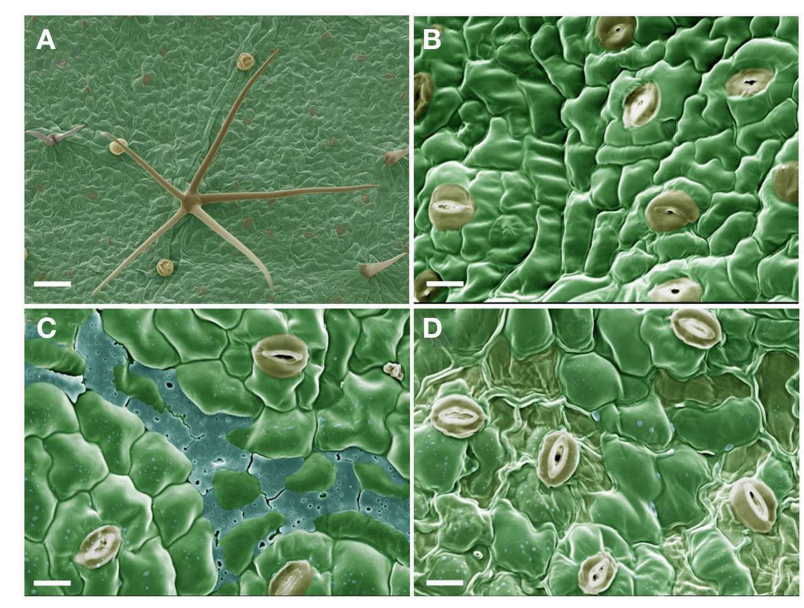

FIGURE 1 | Scanning electron micrographs of the adaxial leaf surface of velvetleaf. (A) 30X magnification and bar $=100 \mu \mathrm{m}$. (B-D) are at 100X magnification and bar $=10 \mu \mathrm{m}$ after 0,1 , and $4 \mathrm{~h}$ exposure to $1 \mathrm{mM}$ sarmentine, respectively.

on the surfaces of epidermal cells as well as a layer accumulating in the grooves between the cells (Figure 1C). The desiccating effect of sarmentine is visible within $8 \mathrm{~h}$ of application as a localized loss of turgor of epidermal cells in areas where sarmentine has accumulated (Figure 1D).

\section{Destabilization of Plasma Membrane Integrity}

Sarmentine caused a light-independent loss of plasma membrane integrity in the cucumber cotyledon discs assays when tested at $100 \mu \mathrm{M}$ or more. At these concentrations, a rapid increase in electrolyte conductivity was measured in the bathing medium within $1 \mathrm{~h}$ or exposure and reached a maximum between 6 and $8 \mathrm{~h}$ exposure (Figure 2). Interestingly, the activity of $30 \mu \mathrm{M}$ sarmentine was low during the dark incubation period, but was greatly stimulated upon light exposure (double arrow on Figure 2).

Pelargonic acid required higher concentrations to cause a similar light-independent loss of membrane integrity, and the activity was not stimulated by the addition of light (Figure 3). Plotting the relationship between inhibitor concentration and conductivity of the bathing solution after $24 \mathrm{~h}$ of incubation in darkness generated reliable dose-response curves that enabled the quantitative comparison of the potency of sarmentine and pelargonic acid (Figure 4).

Analysis of the curves were performed with a four-parameters log-logistic model which enabled the calculation of the $I_{50}$ concentration for these compounds on various weed species (Table 3). Sarmentine was 12.4-29.1 times more active than pelargonic acid and had a more consistent potency across the species tested.

\section{Inhibition of Enoyl-ACP Reductase (ENR)}

Sarmentine has some structural similarity with crotonyl-CoA, the substrate of ENR (Figure 5A). ENR was expressed heterologously in E. coli and purified with a specific activity of $10.13 \pm 1.36 \mathrm{mmol}$

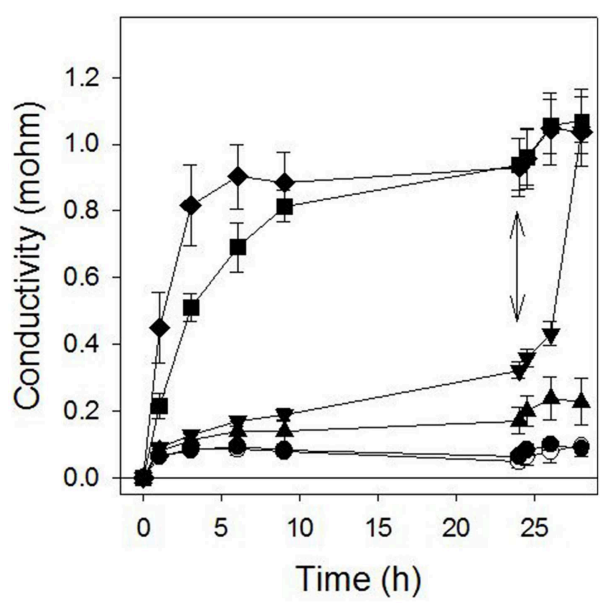

FIGURE 2 | Effect of sarmentine on cucumber membrane integrity as measured in the conductivity of the bathing medium. Samples were incubated in darkness for $24 \mathrm{~h}$ and then exposed to high light intensity. $\bigcirc=$ control; = = $3 \mu \mathrm{M} ; \boldsymbol{\Delta}=10 \mu \mathrm{M} ; \boldsymbol{\nabla}=30 \mu \mathrm{M} ; \boldsymbol{\square}=100 \mu \mathrm{M} ; \boldsymbol{\nabla}=300 \mu \mathrm{M}$ sarmentine. The double arrow marks when the samples were transferred to the light.

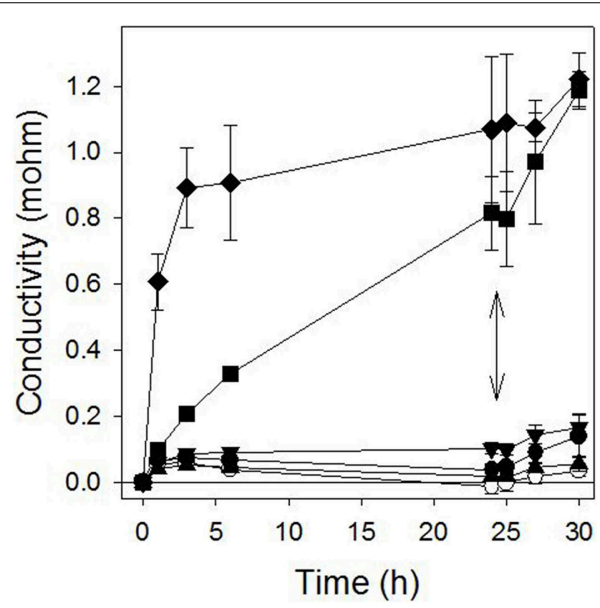

FIGURE 3 | Effect of pelargonic acid on cucumber membrane integrity as measured in the conductivity of the bathing medium. Samples were incubated in darkness for $24 \mathrm{~h}$ and then exposed to high light intensity. $\bigcirc=$ control; $=30 \mu \mathrm{M} ; \boldsymbol{\Lambda}=100 \mu \mathrm{M} ; \boldsymbol{\nabla}=300 \mu \mathrm{M} ; \boldsymbol{\square}=1000 \mu \mathrm{M} ; \bullet=3000 \mu \mathrm{M}$ pelargonic acid. The double arrow marks when the samples were transferred to the light.

NADH $\min ^{-1} \mu \mathrm{g}^{-1}$ protein. Sarmentine inhibited the activity of ENR in a dose-dependent manner with an $I_{50}$ app of $18.3 \mu \mathrm{M}$ (Figure 5B).

\section{Interaction Between Sarmentine and Photosystem II}

The stimulation of electrolyte leakage by light observed at $30 \mu \mathrm{M}$ sarmentine was accompanied with a strong reduction of photosynthetic electron transport, with only $11 \%$ of the total activity after $4 \mathrm{~h}$ incubation in the dark (Figure 6). Direct inhibition of 


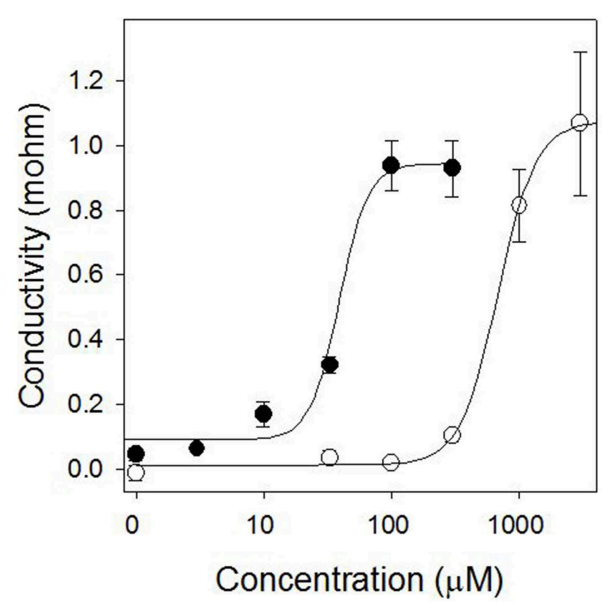

FIGURE 4 | Dose-response curve of sarmentine (O) and pelargonic acid $(O)$ after $24 \mathrm{~h}$ incubation in the dark on membrane integrity in cucumber cotyledons.

TABLE 3 | Effect of sarmentine and pelargonic acid on membrane integrity of cucumber, mustard, redroot pigweed, velvetleaf, crabgrass after $24 \mathrm{~h}$ incubation in darkness.

\begin{tabular}{lccccc}
\hline \multirow{2}{*}{ Species } & Sarmentine & & Pelargonic acid & Potency $^{\mathbf{b}}$ \\
\cline { 2 - 6 } & & & $\boldsymbol{I}_{\mathbf{5 0}}(\boldsymbol{\mu} \mathbf{M})^{\mathbf{a}}$ \\
\hline Cucumber & $38.3 \pm 4.5$ & A & $645 \pm 71$ & A & 16.8 \\
Redroot pigweed & $38.3 \pm 4.6$ & A & $938 \pm 72$ & A & 24.5 \\
Mustard & $74.6 \pm 6.7$ & B & $926 \pm 90$ & A & 12.4 \\
Velvetleaf & $80.3 \pm 3.9$ & B & $2334 \pm 423$ & B & 29.1 \\
Crabgrass & $91.8 \pm 9.4$ & C & $2509 \pm 191$ & B & 27.3
\end{tabular}

a Means values followed by the same letter do not differ significantly at the $5 \%$ level by Duncan's multiple range test.

b Potency of sarmentine relative to pelargonic acid: $I_{50}$ of pelargonic acid//50 of sarmentine.

photosynthesis was confirmed on isolated thylakoid membranes, where sarmentine caused a rapid and dose-dependent inhibition of oxygen evolution, with an $I_{50}$ of $3.0 \pm 0.12 \mu \mathrm{M}$ (Figure 7). On the other hand, pelargonic acid did not inhibit photosynthetic oxygen evolution at concentrations up to $100 \mu \mathrm{M}$.

The ability of sarmentine to inhibit photosynthesis is related to its structural similarity with photosystem II (PSII) inhibitors (Figures 8A,B). In particular, it has an amide group attached to a lipophilic side chain and possesses a nitrogen with a positive $\pi$ charge (Figure 8C). These structural features enabled sarmentine to compete with $\left[{ }^{14} \mathrm{C}\right]$-atrazine for the QB binding site on PSII (Figure 9A). Plotting the slopes of oxygen evolution from the binding kinetic study revealed that sarmentine had an apparent $K_{i}$ of $1.5 \mu \mathrm{M}$ (Figure 9B).

Since sarmentine acted as a PSII inhibitor, its activity was compared to atrazine on thylakoid membranes isolated from wild-type and triazine-resistant pigweed. As expected, atrazine inhibited oxygen evolution of wild-type pigweed thylakoid preparations $\left(I_{50}\right.$ of $\left.0.60 \pm 0.07 \mu \mathrm{M}\right)$, but was ineffective $\left(I_{50}>10 \mu \mathrm{M}\right)$ on thylakoid preparations from triazine-resistant
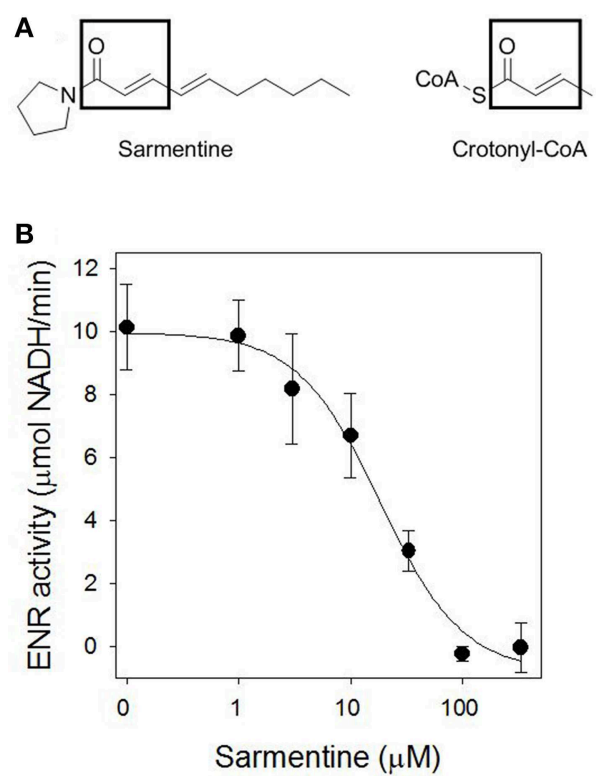

FIGURE 5 | (A) Structure of sarmentine and crotonyl-CoA, and (B) effect of sarmentine on purified Arabidopsis thaliana enoyl-ACP reductase.

pigweed (Figure 10A). Sarmentine, on the other hand, inhibited oxygen evolution from both wild-type and triazine-resistant pigweed, with $I_{50}$ of $1.72 \pm 0.17$ and $0.97 \pm 0.15 \mu \mathrm{M}$, respectively (Figure 10B).

\section{L-Amino Acid Oxidase Assay}

The activity of sarmentine was tested on L-amino acid oxidase to be sure that the mechanism of action of this Piper amide did not involve indiscriminate enzyme inhibition. L-Amino acid oxidase was selected because this FAD-containing enzyme participates in 8 metabolic pathways (alanine, aspartate, methionine, tyrosine, phenylalanine and tryptophan metabolism, valine, leucine and isoleucine degradation, and alkaloid biosynthesis. Sarmentine did not inhibit L-amino acid oxidase (Supplemental Data 1).

\section{Discussion}

\section{Alteration of the Leaf Surface Ultrastructure by Sarmentine}

The appearance of the cuticle and any surface deposit was preserved during the preparation for scanning electron microscopy by avoiding traditional alcohol dehydration and fixation processes. Instead, leaf samples were flash-frozen in nitrogen slush. This process results in ultra-rapid freezing of tissues and prevents the tissue damage associated with the Leidenfrost effect.

The natural appearance of the epidermal cells and cuticular wax layer was preserved in the control samples (Figures 1A,B). The only artifactual features were the slight collapse of the fragile glandular trichomes, but this did not interfere with the interpretation of the micrographs.

The leaf surface of velvetleaf is smooth and void of epicuticular wax crystals (Figure 1), consisting of approximately $36 \%$ 


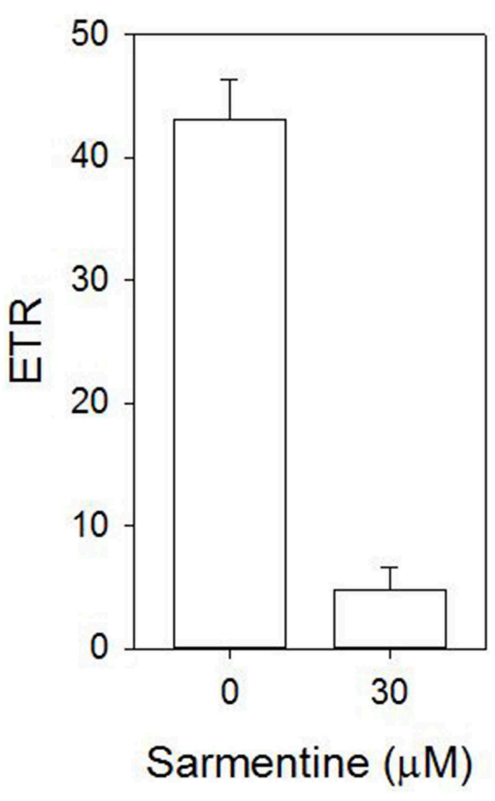

FIGURE 6 | Effect of sarmentine on photosynthetic efficiency of cucumber cotyledons incubated in darkness for $4 \mathrm{~h}$.

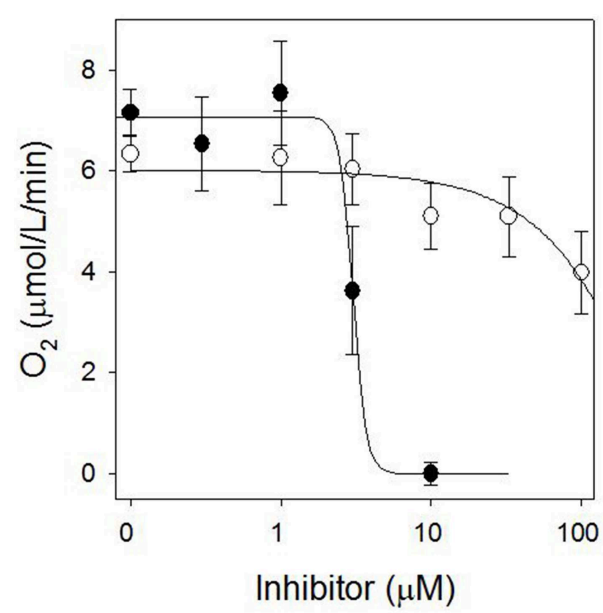

FIGURE 7 | Effect of sarmentine (O) and pelargonic acid $(O)$ on photosynthetic oxygen evolution in isolated spinach thylakoid membranes.

non-polar and 64\% polar lipid components (Harr et al., 1991). Consequently, water droplets have a relatively high contact angle $\left(66^{\circ}\right)$ on the surface of these leaves (Harr et al., 1991). The addition of $0.1 \%$ nonionic surfactant dramatically reduces the contact angle, but for the purpose of this study, sarmentine was applied as a $1 \mathrm{mM}$ solution in water with $1 \%$ acetone. Though less than ideal for the application of this lipophilic phytotoxin [sarmentine has a $\log P$ of 3.07 as calculated according to Ghose et al. (1988)], the absence of surfactants or adjuvants ensures that the presence of sarmentine and its effect on the leaf ultrastructure are observed.

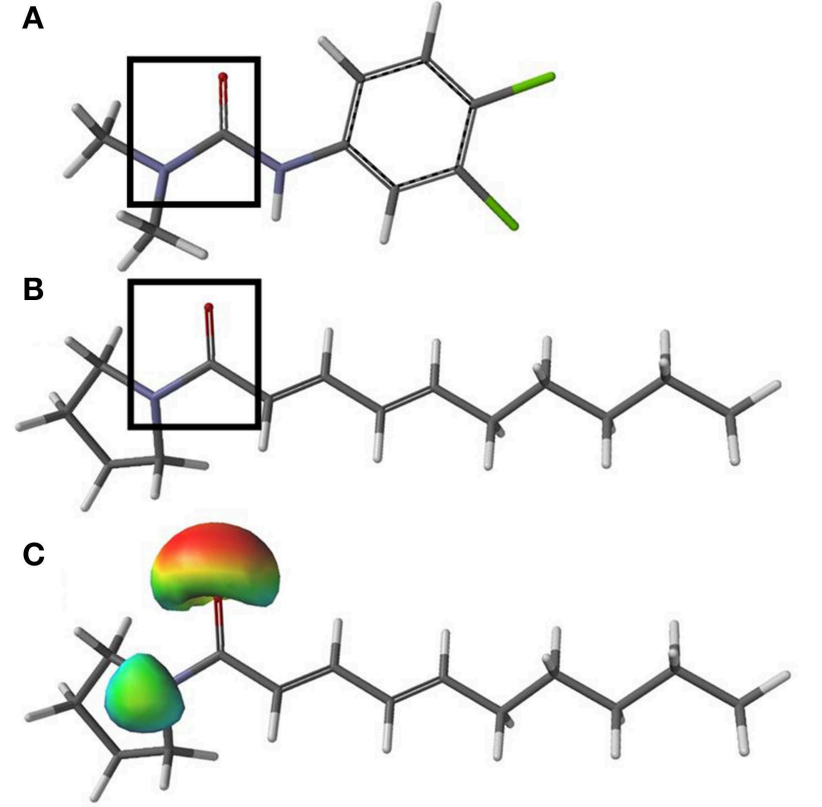

FIGURE 8 | Minimized structure of diuron (A) and sarmentine (B). Black boxes highlight the minimum structural requirements known for "classical" PSII inhibitors. The nitrogen within the boxes carries a positive $\pi$-charge, as illustrated in (C), a surface density showing the positive $\pi$-charge (blue green) of the nitrogen and negative $\pi$-charge (red) of the oxygen atoms. Gray $=$ carbon, white $=$ hydrogen, blue $=$ nitrogen, red $=$ oxygen, and green $=$ chlorine

Sarmentine residues were visible over the cuticular surface and accumulating as a layer within the grooves of the cells within $1 \mathrm{~h}$ of application. No ultrastructural damage is evident within this time frame (Figure 1C), but the collapse of the epidermal cells caused by sarmentine developed within $8 \mathrm{~h}$ of application (Figure 1D). This occurs primarily in the vicinity where sarmentine accumulated. However, there was no clear evidence of stripping of the cuticular wax layer, therefore the burn-down symptoms may be due to the interaction of sarmentine with other physiological processes. No effect on the leaf surface was observed in samples treated with the $1 \%$ acetone solution (data not shown).

\section{Destabilization of Plasma Membrane Integrity}

The plasma membrane is at the interface between the cell and its environment, and serves to holds the entire cellular structure whole. Consequently, destabilization of the lipid bilayer, often via reactive oxygen species (ROS)-induced stress membrane peroxidation, result in uncontrolled electrolyte leakage and in cell death (McKersie et al., 1990; Mittler, 2002). The possibility that sarmentine affects membrane stability was first tested using a standard cucumber cotyledon disc system (Duke and Kenyon, 1993; Dayan and Watson, 2011) and then applied to several weed species. Sarmentine caused a rapid loss of membrane integrity in all species tested, with $I_{50}$ values below $100 \mu \mathrm{M}$ (Figure 2 and Table 3). A $100 \mu \mathrm{M}$ concentration corresponds to $22 \mu \mathrm{g} \mathrm{ml}^{-1}$ or $0.0022 \%$ sarmentine solutions. This is very active for a natural 


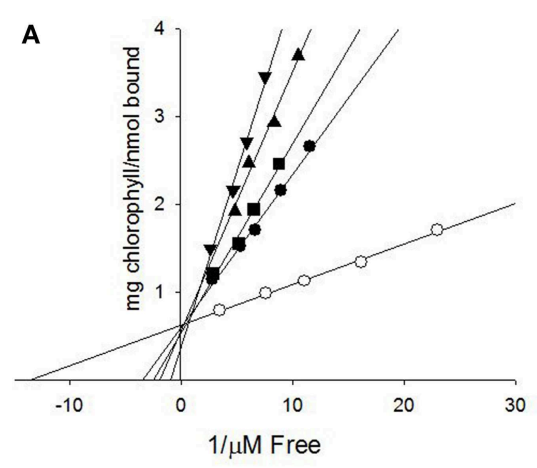

B

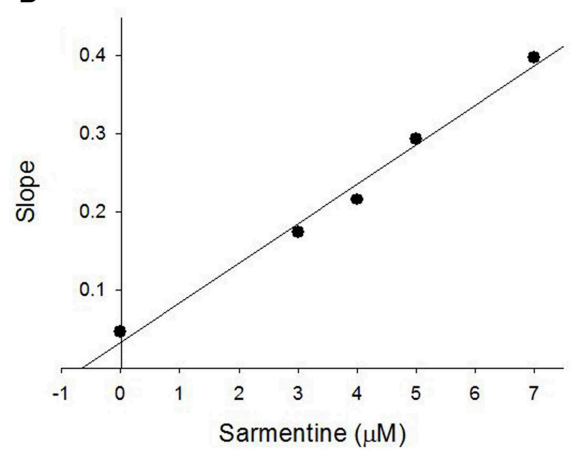

FIGURE 9 | (A) Binding of $\left[{ }^{14} \mathrm{C}\right]$-atrazine to isolated thylakoid membranes and displacement from its binding site by sarmentine. $\bigcirc=0 ; \bigcirc=3 \mu \mathrm{M}$;

$\boldsymbol{\square}=4 \mu \mathrm{M} ; \boldsymbol{\Delta}=5 \mu \mathrm{M} ; \boldsymbol{\nabla}=7 \mu \mathrm{M}$ sarmentine. (B) Estimation of the binding constant of sarmentine on PSIl by plotting the concentration of sarmentine vs. the slope of the regression lines in (A).

product, but this does not mean that sarmentine would be active at this concentration in the greenhouse or in the field because the samples are floating on top of the treatment solution in the cotyledon disc assay.

While the concentration required was higher than with sarmentine, pelargonic acid also caused electrolyte leakage, which is consistent with its known mechanism of action (Figure 3 and Table 3) (Dayan and Watson, 2011). Herbicidal organic soaps are based on fatty acid compositions that strip the cuticular wax layer covering the surface of leaves, resulting in rapid loss of membrane integrity. From structure-activity relationship studies, the optimum lipophilic chain length is $8-9$ carbons (Lederer et al., 2004; Coleman and Penner, 2006). The contribution of the level of unsaturation is not well known, though some unsaturated fatty acids have been patented as herbicides (Killick et al., 1997). On the other hand, the level of unsaturation of the sarmentine's side chain does not appear to contribute to activity (Huang et al., 2010). From that perspective, sarmentine and pelargonic acid appear to act in a similar manner. However, the light-dependent increase in electrolyte leakage observed at $30 \mu \mathrm{M}$ sarmentine is not duplicated by pelargonic acid, which would be expected if the two compounds had exactly the same mechanisms of action.

\section{Inhibition of Enoyl-ACP Reductase (ENR)}

The loss of membrane integrity can be the result of oxidative stress generated by the accumulation of ROS (Dayan and

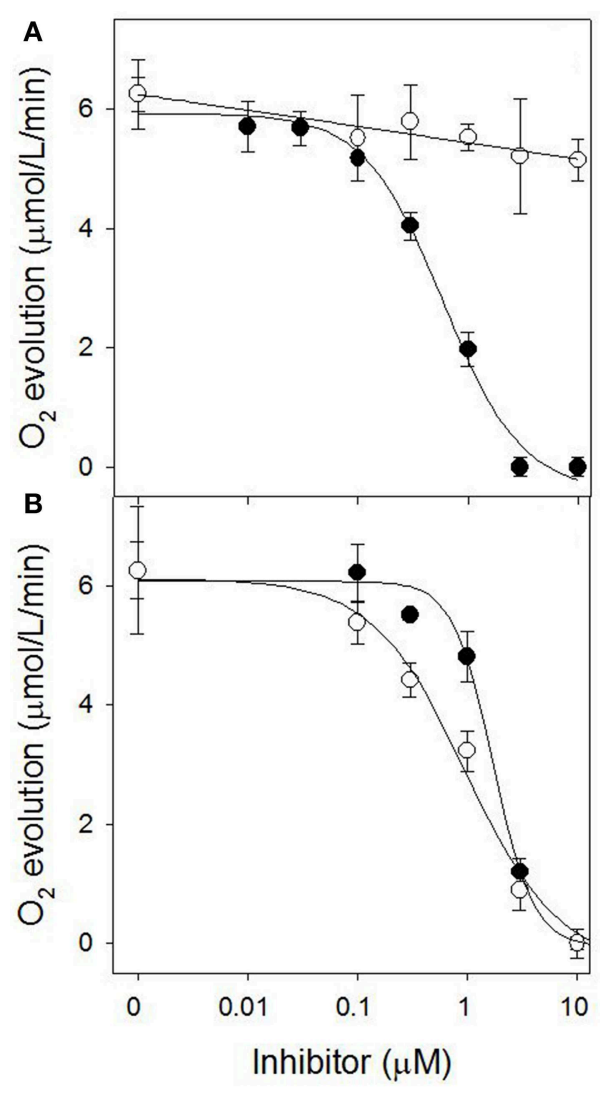

FIGURE 10 | (A) Effect of atrazine on $\mathrm{O}_{2}$ evolution from thylakoid membrane extracted from susceptible $(\mathbf{O})$ or triazine-resistant $(\bigcirc)$ pigweed. (B) Effect of sarmentine on $\mathrm{O}_{2}$ evolution from thylakoid membrane extracted from susceptible $(\mathbf{O})$ or triazine-resistant $(\bigcirc)$ pigweed.

Watson, 2011), but can also result from the inhibition of fatty acid synthesis, as documented with triclosan (McMurry et al., 1998; Heath et al., 1999). In plants, fatty acid biosynthesis is compartmentalized in the chloroplast and catalyzed by a type II fatty acid synthase (FAS). The last step in each elongation cycle is carried out by the enoyl-[ACP]-reductase (ENR), which reduces the dehydrated product of $\beta$-hydroxyacyl-[ACP] dehydrase using NADPH or NADH (González-Thuillier et al., 2015). The diphenyl ethers triclosan (a synthetic antimicrobial compound) and cyperin (a fungal metabolite) cause the light-independent loss of membrane integrity by inhibiting ENR (McMurry et al., 1998; Dayan et al., 2008). The possibility that sarmentine also inhibited ENR was explored in part because of the structural similarity between sarmentine and crotonyl-CoA, the substrate of ENR (Figure 5A).

Sarmentine inhibited ENR, with an $I_{50}=18.3 \pm 4.4 \mu \mathrm{M}$, which was much more active than the natural ENR inhibitor cyperin, with an $I_{50}=89.0 \pm 15.1 \mu \mathrm{M}$. This is not a very potent level of activity compared to triclosan, the most common ENR inhibitor, which has an apparent $I_{50}$ of $46 \pm 5 \mathrm{nM}$ (Dayan et al., 2008). Cyperin and triclosan are diphenyl ethers that are stabilized within the binding pocket of ENR by $\pi-\pi$ stacking between one of their phenyl rings and the nicotinamide ring of the NAD ${ }^{+}$ 
and hydrogen bonding with the side chain of a tyrosine (Heath et al., 1999; Dayan et al., 2008). The binding of sarmentine on ENR is not known.

\section{Interaction Between Sarmentine and Photosystem II}

Sarmentine destabilized plasma membranes at high concentration $(100 \mu \mathrm{M}$ or more), but its activity on electrolyte leakage was minimal at $30 \mu \mathrm{M}$ (inverted triangle in Figure 2) in darkness. However, its activity increased dramatically upon exposure to light (after the double arrow on Figure 2). This suggests that one of the mechanisms of action of sarmentine involves one of the light-dependent photosynthetic processes.

Photosynthesis is the target of many synthetic herbicides and natural phytotoxins (Draber et al., 1991; Trebst, 2007; Dayan and Duke, 2014). The most common mechanism of action involves inhibition of electron transport on PSII by competing for the binding of plastoquinone on the QB protein. Many of these are typical PSII inhibitors that may or may not compete with the same binding site as atrazine (e.g., sorgoleone, tenuazonic acid) (Einhellig et al., 1993; Czarnota et al., 2001; Chen et al., 2007). However, the other steps of photosynthetic electron transport can be inhibited by natural products as well. For example, stimatellin and certain aurachins interfere with electron transport at the level of cytochrome b6/f complex (Oettmeier et al., 1985, 1990), and the Streptomyces phytotoxin pyridazocidin diverts electrons from photosystem I in a similar way as paraquat (Gerwick et al., 1997).

Sarmentine completely halted electron transport at $30 \mu \mathrm{M}$ after $4 \mathrm{~h}$ dark incubation (Figure 4), which is consistent with inhibition of PSII (Dayan and Zaccaro, 2012). Its direct interference of photosynthesis was confirmed by dose-dependent inhibition of oxygen evolution, whereas pelargonic acid was not active (Figure 7). This suggests that the effect on photosynthetic electron transfer is not due to the indirect destabilization of the chloroplast membrane, but rather by direct inhibition of the electron flow in a manner similar to that of diuron or atrazine (Trebst, 2007; Dayan et al., 2010; Dayan and Zaccaro, 2012).

Sarmentine has several of the structural features typical to certain synthetic and natural PSII inhibitors. The minimum structural requirements for these inhibitors include an amide group connected to a lipophilic side chain (Trebst and Draber, 1986). This structural requirement evident in the phenylurea herbicide diuron (Figure 8A) is also present in sarmentine (Figure 8B).

\section{References}

Alécio, A. C., Bolzani, V. D. S., Young, M. C. M., Kato, M. J., and Furlan, M. (1998). Antifungal amide from leaves of Piper hispidum. J. Nat. Prod. 61, 637-639. doi: $10.1021 / \mathrm{np} 9703656$

Banerji, A., and Das, C. (1989). Two amides from Piper brachystachyum. Phytochemistry 28, 3039-3042. doi: 10.1016/0031-9422(89)80275-4

Barker, A. V., and Prostak, R. G. (2009). Alternative management of roadside vegetation. Horttechnology 19, 346-352. Available online at: horttech.ashspublications.org/content/19/2/346.full
Typically, the nitrogen carries a positive $\pi$-charge that is important for the binding of the herbicide to the $\mathrm{Q}_{\mathrm{B}}$ domain of PSII (Ohad and Hirschberg, 1992). Analysis of the partial charge distribution on sarmentine illustrates the presence of such a feature in sarmentine, where the unpaired electrons of the amine are shared with the oxygen of the carbonyl group (Figure 8C).

Final evidence of the effect of sarmentine on PSII consists of its ability to displace atrazine bound to the QB protein (Figure 9A). Taken together, these experiments suggest that sarmentine has a $K_{\mathrm{i}}$ of $1.5 \mu \mathrm{M}$, which is better than some other natural products like tenuazonic acid at $147 \mu \mathrm{M}$ (Chen et al., 2008) but not as good as most synthetic herbicides (Tischer and Strotmann, 1977). Interestingly, sarmentine inhibited the electron flow from thylakoid membranes isolated from triazine-resistant pigweed, whereas atrazine was only active on the wild-type pigweed (Figure 10). This is similar to what has been reported with other natural PSII inhibitors. There are two known binding sites on the Qb protein (Oettmeier et al., 1982). The Ser264 family (also called the classical family) is important for the binding of triazine-type inhibitors, whereas the His215 family (also called the quinone or phenolic family) is important for the binding of quinone-type inhibitors (Dayan et al., 2009a). Consequently, a mutation of Ser264 to Gly or Ala causes resistance to triazines, but not to other inhibitors (Dayan et al., 2009a).

In conclusion, application of sarmentine results in rapid desiccation of the foliage but its herbicidal activity is more complex than the physical removal of cuticle associated with organic soap herbicides (Coleman and Penner, 2006, 2008). Indeed, the loss of plasma membrane integrity is the consequence of at least two mechanisms of action. Sarmentine crosses the cuticle and penetrates the cells where it interferes with fatty acid synthesis by inhibiting ENR and with photosynthesis by competing for the binding of plastoquinone on PSII.

\section{Acknowledgments}

This research was supported in part by a Material Transfer and Research Agreement (58-6408-4-009) with Marrone BioInnovations.

\section{Supplementary Material}

The Supplementary Material for this article can be found online at: http://www.frontiersin.org/journal/10.3389/fpls.2015. 00222/abstract 
Coleman, R., and Penner, D. (2006). Desiccant activity of short chain fatty acids. Weed Technol. 20, 410-415. doi: 10.1614/WT-05-117R.1

Coleman, R., and Penner, D. (2008). Organic acid enhancement of pelargonic acid. Weed Technol. 22, 38-41. doi: 10.1614/WT-06-195.1

Czarnota, M. A., Paul, R. N., Dayan, F. E., Nimbal, C. I., and Weston, L. A. (2001). Mode of action, localization of production, chemical nature, and activity of sorgoleone: a potent PSII inhibitor in Sorghum spp. root exudates. Weed Technol. 15, 813-825. doi: 10.1614/0890-037X(2001)015[0813:MOALOP]2.0.CO;2

Da Silva, J. K. R., Pinto, L. C., Burbano, R. M. R., Montenegro, R. C., Guimarães, E. F., Andrade, E. H. A., et al. (2014). Essential oils of Amazon Piper species and their cytotoxic, antifungal, antioxidant and anti-cholinesterase activities. Ind. Crops Prod. 58, 55-60. doi: 10.1016/j.indcrop.2014.04.006

Dayan, F. E., and Duke, S. O. (2014). Natural compounds as next generation herbicides. Plant Physiol. 166, 1090-1105. doi: 10.1104/pp.114. 239061

Dayan, F. E., Duke, S. O., and Grossmann, K. (2010). Herbicides as probes in plant biology. Weed Sci. 58, 340-350. doi: 10.1614/WS-09-092.1

Dayan, F. E., Ferreira, D., Wang, Y.-H., Khan, I. A., McInroy, J. A., and Pan, Z. (2008). A pathogenic fungi diphenyl ether phytotoxin targets plant enoyl (acyl carrier protein) reductase. Plant Physiol. 147, 1062-1071. doi: $10.1104 /$ pp.108.118372

Dayan, F. E., Howell, J. L., and Weidenhamer, J. D. (2009a). Dynamic root exudation of sorgoleone and its in planta mechanism of action. J. Exp. Bot. 60, 2107-2117. doi: 10.1093/jxb/erp082

Dayan, F. E., Owens, D. K., Corniani, N., Silva, F. M. L., Watson, S. B., Howell, J. L., et al. (2015). Biochemical markers and enzyme assays for herbicide mode of action and resistance studies. Weed Sci. 63, 23-63. doi: 10.1614/WS-D-1300063.1

Dayan, F. E., Owens, D. K., and Duke, S. O. (2012). Rationale for a natural products approach to herbicide discovery. Pest Manag. Sci. 68, 519-528. doi: $10.1002 /$ ps.2332

Dayan, F. E., Romagni, J. G., and Duke, S. O. (2000a). Investigating the mode of action of natural phytotoxins. J. Chem. Ecol. 26, 2079-2094. doi: 10.1023/A:1005512331061

Dayan, F. E., Trindade, M. L. B., and Velini, E. D. (2009b). Amicarbazone, a new photosystem II inhibitor. Weed Sci. 57, 579-583. doi: 10.1614/WS-09-099.1

Dayan, F. E., Vincent, A., Romagni, J. G., Allen, S. N., Duke, S. O., Duke, M. V., et al. (2000b). Amino- and urea-substituted thiazoles inhibit photosynthetic electron transfer. J. Agric. Food Chem. 48, 3689-3693. doi: 10.1021/ jf9911545

Dayan, F. E., and Watson, S. B. (2011). Plant cell membrane as a marker for light-dependent and light-independent herbicide mechanisms of action. Pestic. Biochem. Physiol. 101, 182-190. doi: 10.1016/j.pestbp.2011.09.004

Dayan, F. E., and Zaccaro, M. L. D. M. (2012). Chlorophyll fluorescence as a marker for herbicide mechanisms of action. Pestic. Biochem. Physiol. 102, 189-197. doi: 10.1016/j.pestbp.2012.01.005

Délye, C., Jasieniuk, M., and Le Corre, A. V. (2013). Deciphering the evolution of herbicide resistance in weeds. Trends Gen. 29, 649-658. doi: 10.1016/j.tig.2013.06.001

De Mendiburu, F. (2014). Agricolae Version 1.1-4. Practical Manual. 1-60. Available online at: tarwi.lamolina.edu.pe/ fmendiburu

Draber, W., Tietjen, K., Kluth, J. F., and Trebst, A. (1991). Herbicides in photosynthesis research. Angew. Chem. Int. Ed. 30, 1621-1633. doi: 10.1002/anie.199116211

Duke, S. O., Bajsa, J., and Pan, Z. (2013). Omics methods for probing the mode of action of natural and synthetic phytotoxins. J. Chem. Ecol. 39, 333-347. doi: 10.1007/s10886-013-0240-0

Duke, S. O., and Kenyon, W. H. (1993). "Peroxidizing activity determined by cellular leakage," in Target Assays for Modern Herbicides and Related Compounds, eds P. Böger and G. Sandmann (Boca Raton: Lewis Publishers), 61-66.

Dyer, L. A., Dodson, C. D., Beihoffer, J., and Letourneau, D. K. (2001). Tradeoffs in antiherbivore defenses in Piper cenocladum: ant mutualists versus plant secondary metabolites. J. Chem. Ecol. 27, 581-592. doi: 10.1023/A:10103 45123670

Dyer, L., Richards, J., and Dodson, C. D. (2004). "Isolation, synthesis, and evolutionary ecology of Piper amides," in Piper: A Model Genus for Studies of Phytochemistry, Ecology, and Evolution, eds L. Dyer and A. N. Palmer (New York, NY: Springer US), 117-139.
Einhellig, F. A., Rasmussen, J. A., Hejl, A. M., and Souza, I. F. (1993). Effects of root exudate sorgoleone on photosynthesis. J. Chem. Ecol. 19, 369-375. doi: 10.1007/BF00993702

Fukuda, M. Y., Tsujino, Y., Fujimori, T., Wakabayashi, K., and Böger, P. (2004). Phytotoxic activity of middle-chain fatty acids I: effects on cell constituents. Pestic. Biochem. Physiol. 80, 143-150. doi: 10.1016/j.pestbp.2004.06.011

Gerwick, B. C., Fields, S. S., Graupner, P. R., Gray, J. A., Chapin, E. L., Cleveland, J. A., et al. (1997). Pyridazocidin, a new microbial phytotoxin with activity in the Mehler reaction. Weed Sci. 45, 654-657.

Gerwick, B. C., and Sparks, T. C. (2014). Natural products for pest control: an analysis of their role, value and future. Pest Manag. Sci. 70, 1169-1185. doi: $10.1002 /$ ps.3744

Ghose, A. K., Pritchett, A., and Crippen, G. M. (1988). Atomic physicochemical parameters for three dimensional structure directed quantitative structureactivity relationships III: modeling hydrophobic interactions. J. Comp. Chem. 9, 80-90. doi: 10.1002/jcc.540090111

Gianessi, L. P., and Reigner, N. P. (2007). The value of herbicides in U. S. crop production. Weed Technol. 21, 559-566. doi: 10.1614/WT-06-130.1

González-Thuillier, I., Venegas-Calerón, M., Garcés, R., Von Wettstein-Knowles, P., and Martínez-Force, E. (2015). Sunflower (Helianthus annuus) fatty acid synthase complex: enoyl-[acyl carrier protein]-reductase genes. Planta 241, 43-56. doi: 10.1007/s00425-014-2162-7

Harr, J., Guggenheim, R., Schulke, G., and Falk, R. (1991). The Leaf Surface of Major Weeds. Witterswil: Sandoz Agro Ltd.

Hayat, M. A. (ed.) (2000). "Low temperature methods," in Principles and Techniques of Electron Microscopy: Biological Applications, 4th Edn. (Cambridge: Cambridge University Press), 400-438.

Heap, I. (2015). The International Survey of Herbicide Resistant Weeds [Online]. Available online at: http://www.weedscience.org (Accessed January 8, 2015).

Heath, R. J., Rubin, J. R., Holland, D. R., Zhang, E., Snow, M. E., and Rock, C. O. (1999). Mechanism of triclosan inhibition of bacterial fatty acid synthesis. J. Biol. Chem. 274, 11110-11114. doi: 10.1074/jbc.274.16.11110

Huang, H., Morgan, C. M., Asolkar, R. N., Koivunen, M. E., and Marrone, P. G. (2010). Phytotoxicity of sarmentine isolated from long pepper (Piper longum) fruit. J. Agric. Food Chem. 58, 9994-10000. doi: 10.1021/jf102087c

Hüter, O. F. (2011). Use of natural products in the crop protection industry. Phytochem. Rev. 10, 185-194. doi: 10.1007/s11101-010-9168-y

Killick, R. W., Wrigley, P. R., Jones, P. W., and Schulteis, D. T. (1997). Herbicide, Crop Desiccant and Defolliant Adjuvants Comprising an Unsaturated Fatty Acid Ethyl Ester and a Non-Ionic Emulsifier. US5631205 A. Washington, DC: USPTO.

Koch, M. A., Schuffenhauer, A., Scheck, M., Wetzel, S., Casaulta, M., Odermatt, A., et al. (2005). Charting biologically relevant chemical space: a structural classification of natural products (SCONP). Proc. Natl. Acad. Sci. U.S.A. 102, 17272-17277. doi: 10.1073/pnas.0503647102

Lederer, B., Fujimori, T., Tsujino, Y., Wakabayashi, K., and Böger, P. (2004). Phytotoxic activity of middle-chain fatty acids II: peroxidation and membrane effects. Pestic. Biochem. Physiol. 80, 151-156. doi: 10.1016/j.pestbp.2004.06.010

Li, C. Y., Tsai, W., Damu, A. G., Lee, E. J., Wu, T. S., Dung, N. X., et al. (2007). Isolation and identification of antiplatelet aggregatory principles from the leaves of Piper lolot. J. Agric. Food Chem. 55, 9436-9442. doi: 10.1021/jf0719631

Li, J. W.-H., and Vederas, J. C. (2009). Drug discovery and natural products: end of an era or an endless frontier. Science 325, 161-165. doi: 10.1126/science. 1168243

Likhitwitayawuid, K., Ruangrungsi, N., Lange, G. L., and Decicco, C. P. (1987). Structural elucidation and synthesis of new components isolated from Piper sarmentosum (Piperaceae). Tetrahedron 43, 3689-3694. doi: 10.1016/S00404020(01)86856-3

Lipkus, A. H., Yuan, Q., Lucas, K. A., Funk, S. A., Bartelt, W. F., III, Schenck, R. J., et al. (2008). Structural diversity of organic chemistry. A scaffold analysis of the CAS Registry. J. Org. Chem. 73, 4443-4451. doi: 10.1021/jo8001276

McKersie, B. D., Hoekstra, F. A., and Krieg, L. C. (1990). Differences in the susceptibility of plant membrane lipids to peroxidation. Biochim. Biophys. Acta 1030, 119-126. doi: 10.1016/0005-2736(90)90246-K

McMurry, L. M., McDermott, P. F., and Levy, S. B. (1998). Triclosan targets lipid synthesis. Nature 394, 531-532. doi: 10.1038/28970

Mittler, R. (2002). Oxidative stress, antioxidants and stress tolerance. Trends Plant Sci. 7, 405-410. doi: 10.1016/S1360-1385(02)02312-9 
Oettmeier, W., Dostatni, R., Majewski, C., Hoefle, G., Fecker, T., Kunze, B., et al. (1990). The aurachins, naturally occurring inhibitors of photosynthetic electron flow through photosystem II and cytochrome b6/f-complex. Z. Naturforsch. $45 \mathrm{C}, 322-328$.

Oettmeier, W., Godde, D., Kunze, B., and Hoefle, G. (1985). Stigmatellin. A dual type inhibitor of photosynthetic electron transport. Biochim. Biophys. Acta 807, 216-219. doi: 10.1016/0005-2728(85)90125-2

Oettmeier, W., Masson, K., and Johanningmeier, U. (1982). Evidence for two different herbicide-binding proteins at the reducing side of Photosystem II. Biochim. Biophys. Acta 679, 376-383. doi: 10.1016/0005-2728(82) 90157-8

Ohad, N., and Hirschberg, J. (1992). Mutations in the D1 subunit of photosystem II distinguish between quinone and herbicide binding sites. Plant Cell 4, 273-282. doi: $10.1105 /$ tpc.4.3.273

Parmar, V. S., Jain, S. C., Bisht, K. S., Jain, R., Taneja, P., Jha, A., et al. (1997). Phytochemistry of the genus Piper. Phytochemistry 46, 597-673. doi: 10.1016/S00319422(97)00328-2

Rimando, A. M., Dayan, F. E., Czarnota, M. A., Weston, L. A., and Duke, S. O. (1998). A new photosystem II electron transfer inhibitor from Sorghum bicolor. J. Nat. Prod. 61, 927-930. doi: 10.1021/np9800708

Ritz, C., and Streibig, J. C. (2005). Bioassay analysis using R. J. Stat. Softw. 12, 1-22. Available online at: www.jstatsoft.org/v12/i05

Rukachaisirikul, T., Siriwattanakit, P., Sukcharoenphol, K., Wongvein, C., Ruttanaweang, P., Wongwattanavuch, P., et al. (2004). Chemical constituents and bioactivity of Piper sarmentosum. Ethnopharmacology 93, 173-176. doi: 10.1016/j.jep.2004.01.022

Scott, I. M., Jensen, H. R., Philogène, B. J. R., and Arnason, J. T. (2008). A review of Piper spp. (Piperaceae) phytochemistry, insecticidal activity and mode of action. Phytochem. Rev. 7, 65-75. doi: 10.1007/s11101-0069058-5

Seefeldt, S. S., Jensen, J. E., and Fuerst, E. P. (1995). Log-logistic analysis of herbicide dose-response relationships. Weed Technol. 9, 218-227.

Service, R. F. (2013). What happens when weed killers stop killing? Science 341, 1329. doi: $10.1126 /$ science.341.6152.1329

Solomon, G. M., and Schettler, T. (2000). Environment and health: 6. Endocrine disruption and potential human health implications. Can. Med. Assoc. J. 163, 1471-1476. Available online at: www.cmaj.ca/content/163/11/1471.full

Stillerman, K. P., Mattison, D. R., Giudice, L. C., and Woodruff, T. J. (2008). Environmental exposures and adverse pregnancy outcomes: a review of the science. Reprod. Sci. 15, 631-650. doi: 10.1177/1933719108322436
Tischer, W., and Strotmann, H. (1977). Relationship between inhibitor binding by chloroplasts and inhibition of photosynthetic electron transport. Biochim. Biophys. Acta 460, 113-125. doi: 10.1016/0005-2728(77)90157-8

Trebst, A. (2007). Inhibitors in the functional dissection of the photosynthetic electron transport system. Photosynth. Res. 92, 217-224. doi: 10.1007/s11120007-9213-x

Trebst, A., and Draber, W. (1986). Inhibitors of photosystem II and the topology of the herbicide and $\mathrm{Q}_{B}$ binding polypeptide in the thylakoid membrane. Photosynth. Res. 10, 381-392. doi: 10.1007/BF00118304

Tuntiwachwuttikul, P., Phansa, P., Pootaeng-On, Y., and Taylor, W. C. (2006). Chemical constituents of the roots of Piper sarmentosum. Chem. Pharm. Bull. 54, 149-151. doi: 10.1248/cpb.54.149

Valli, M., Dos Santos, R. N., Figueira, L. D., Nakajima, C. H., Castro-Gamboa, I., Andricopulo, A. D., et al. (2013). Development of a natural products database from the biodiversity of Brazil. J. Nat. Prod. 76, 439-444. doi: $10.1021 / \mathrm{np} 3006875$

Wang, Y.-H., Morris-Natschke, S. L., Yang, J., Niu, H.-M., Long, C.-L., and Lee, K.-H. (2014). Anticancer principles from medicinal Piper (胡椒 Hú Jiāo) plants. J. Tradit. Complement. Med. 4, 8-16. doi: 10.4103/2225-4110.124811

Ward, W. H. J., Holdgate, G. A., Rowsell, S., McLean, E. G., Pauptit, R. A., Clayton, E., et al. (1999). Kinetic and structural characteristics of the inhibition of enoyl (acyl carrier protein) reductase by triclosan. Biochemistry 38, 12514-12525. doi: 10.1021/bi9907779

Yang, Y.-C., Lee, S.-G., Lee, H.-K., Kim, M.-K., Lee, S.-H., and Lee, H.-S. (2002). A piperidine amide extracted from Piper longum L. fruit shows activity against Aedes aegypti mosquito larvae. J. Agric. Food Chem. 50, 3765-3767. doi: $10.1021 /$ jf011708f

Young, S. L. (2004). Natural product herbicides for control of annual vegetation along roadsides. Weed Technol. 18, 580-587. doi: 10.1614/WT-03-094R3

Conflict of Interest Statement: The authors declare that the research was conducted in the absence of any commercial or financial relationships that could be construed as a potential conflict of interest.

Copyright (c) 2015 Dayan, Owens, Watson, Asolkar and Boddy. This is an openaccess article distributed under the terms of the Creative Commons Attribution License (CC BY). The use, distribution or reproduction in other forums is permitted, provided the original author(s) or licensor are credited and that the original publication in this journal is cited, in accordance with accepted academic practice. No use, distribution or reproduction is permitted which does not comply with these terms. 